\title{
Fire in Protected Areas - the Effect of Protection and Importance of Fire Management
}

\author{
Paulo Pereira $^{1}$, Pranas Mierauskas ${ }^{1}$, Xavier Úbeda ${ }^{2}$, Jorge Mataix-Solera ${ }^{3}$ \\ and Artemi Cerda ${ }^{4}$ \\ ${ }^{1}$ Department of Environmental Policy, Mykolas Romeris University, Vilnius, Lithuania. \\ ${ }^{2}$ Department of Physical Geograpgy and Geographic Regional Analysis, University of Barcelona, Barcelona, \\ Spain \\ ${ }_{3}^{3}$ Department of Agrochemistry and Environment, Miguel Hernández University Elche, Alicante, Spain \\ ${ }^{4}$ Department of Geography. University of Valencia, Valencia, Spain \\ crossref http://dx.doi.org/10.5755/j01.erem.59.1.856
}

(received in December, 2011, accepted in March, 2012)

\begin{abstract}
Fires are important but socially and economically unwanted disturbances of the ecosystems. They cannot be considered as a problem, they are global phenomena. Protected areas are created to protect biodiversity, and strict protection is often applied, forgetting that fire had shaped that that we aim to protect. This harsh protection is producing important changes in the protected habitats and is increasing their vulnerability to destructive wildfires. Thus, it is of major interest to incorporate fire management in the protected areas plan, including the (re)use of prescribed fire and traditional burning in order to reintroduce fire regimens, fundamental to the landscape sustainability. This incorporation represents an enormous step in the habitats sustainability. Policies should be more focused on fire prevention than on its suppression.
\end{abstract}

Keywords: Fire, disturbance, protected areas, habitat management, conservation policy.

\section{Introduction}

Fires are the major disturbance of the earth ecosystems, and it is impossible to understand plant and ecosystem evolution without considering their impact (Bond and Kelley 2005; Pausas and Kelley 2009). During the whole geological period fire shaped the landscape without human intervention. More than a disease, fire has to be considered a natural element of the ecosystems. More recently during the historical period, fire was used by men to landscape management, and there are ecosystems in the world (e.g. Mediterranean) whose functions without fire cannot be understood (Pereira et al. 2010; MataixSolera and Cerdà 2010). Thus, it is easy to realize that fire were, are, and will be a common visitor of our landscapes. We assume that fire is a natural component of our ecosystems, however wildfires (non-controlled fires) often pose important threats to public safety, properties, and forest resources (Martell 2007).

Wildfires are observed in Europe as important phenomena that create serious disturbances in our society, and frequently they lead to economical and societal problems, and loss of lives, as observed in Portugal in 2003, Greece in 2009, and more recently in Russia. Wildfires are not only a Mediterranean problem, they should be extended to all ecosystems of Europe and the world, especially in a context of climate warming, where drier and warmer conditions are expected (Rego et al. 2010).

Under favorable conditions of last summer for fire occurrence, fires occurred not only in Mediterranean, but they were frequent visitors in northern latitudes (Fig. 1a and b). The EU put the topic of fire at the top importance level, and many 
projects are ongoing regarding fire management and fire effects on the ecosystems (e.g. FireParadox, www.fireparadox.org, and FireSmart www.firesmartproject.eu).

There is also a growing concern in the EU about protection of the natural areas with of view to avoiding the loss of biodiversity. In the last 25 years the EU has created a total of 26.000 protected areas with more than $750.000 \mathrm{~km}^{2}$, which occupy $18 \%$ of the EU land area and embrace more than $90 \%$ of all the European protected wilderness sites. These areas are connected to each other and are known as Natura 2000 areas, the largest network of protected areas in the world and are important for citizens to attach and recognize the importance of biodiversity (StachuraSkierczynska and Walsh 2010). The basic idea and objectives of Natura 2000 are described by Pereira and Braga (2009).

Protected areas are based on a myth that nature is separated from the people and nature is negatively affected when humans try to live on its resources (Lewis 1996). More than strict protection, these areas should be spaces of interaction between man, nature, and culture from a sustainable point of view and not ghettos, where everything is forbidden (Pereira and Braga 2009). For this be a reality, it is important to develop the best managing practices that in fact are one of the first aims of the European commission (http://ec.europa.eu/environment/nature/index_en.htm ), where..." Natura 2000 is not merely a system of strict nature reserves where human activities are systematically excluded. It adopts a different approach - Natura 2000 fully recognizes that man is an integral part of nature and the two work best in partnership with one another. Indeed, many sites in the Natura 2000 Network are valuable precisely because of the way they have been managed up to now", and "...The management of Natura 2000 sites is therefore best done by working closely with the landowners and stakeholder groups in or around individual Natura 2000 sites in order to agree on the most appropriate ways to conserve the species and habitats, whilst respecting the local socio-economic and cultural context...”.

Despite the existence of legislation, a great number of Natura 2000 areas have management problems. The current management policies in the EU are inadequate and insufficient for maintaining the ecological integrity of Natura 2000 areas (StachuraSkierczynska and Walsh 2010). The problems related to the lack of management and/or its deficient implementations are the basis for creation of unsustainable protected areas and conflicts (Bouwma et al. 2010).

From the ecological and anthropogenic point of view, these areas are very suitable for the fires occurrence. During the summer of 2009, approximately $30 \%$ of the burnt areas occurred in Natura 2000. Those sites were seriously affected and now they face great challenges of recovering to the pre-fire conditions (Rego et al. 2010). Several reports show an increase in forest fires in protected areas around the world (Thackway and Olsson 1999; Ramos-Neto and Pivello 2000, Curran et al. 2004; Pedrosa and Herrmann 2007).

The aim of this paper is: a) to realize the role of protected area management effectiveness and the importance of the incorporation of fire for a better management, b) to realize the role and effects of fire in protected areas, and c) de-management of protected areas with fire.
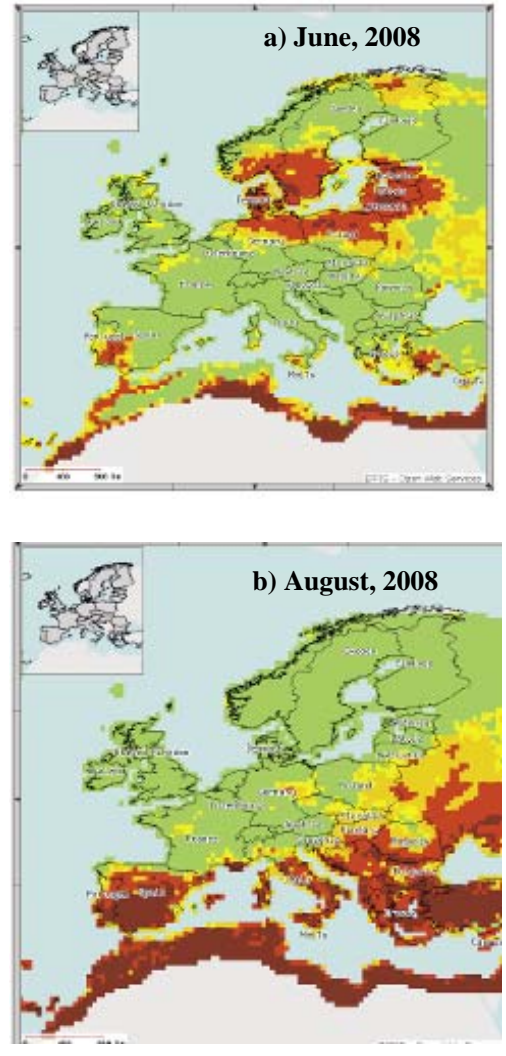

Fig. 1. Forest fire risk in Europe. a) June 2008, b) August 2008. Source: Rego et al. (2010)

\section{Protected areas, the importance of management plan and its effectiveness}

Presently the protected areas face many threats especially due to human expansion (Wittemeyer et al. 2008) and climate change (Cole 2008). The management of protected areas assumes a vital priority to be allocated to regulation of human activities and adaptation to climate change in an increasing spatial area. Management plans should contain the elements described in Table 1 . However, they do not guarantee that these areas will be managed effectively (Nolte et al. 2010). Presently, due to a great increase in protected areas management effectiveness represents a challenge for biodiversity, cultural and historical values by local and national governments, local communities, and NGOs. The society is also making greater investment of human resources, money, and land in protected areas, and there is a need of justification of the budget 
management. The investors should get answers to some questions, such as (Leverington et al. 2010):

- Are protected areas effectively conserving the values for which they exist?

- Is management of these areas effective and how can it be improved?

- Are specific projects, interventions and management activities achieving their objectives, and how can they be improved?
Management effectiveness is defined as the evaluation of how well the protected areas are being managed, and how and to what extent this management is achieving the goals and objectives (Hockings et al. 2006). According to these authors, the effectiveness of protected area management reflects the integration and design of individual sites and protected area systems, the adequacy of protected area systems and processes, and the delivery of protected area aims, considering also the conservation values

Table 1. Recommended elements for protected area management. Source: Lee and Middelton (2003)

\begin{tabular}{|c|c|}
\hline Elements & Contents \\
\hline $\begin{array}{l}\text { ecutive } \\
\text { nmary }\end{array}$ & Résumé of the most important topics of the plan (e.g. management decisions) \\
\hline iction & $\begin{array}{l}\text { - Description of the aims, background situation, and the motive why the protected area } \\
\text { was created (e.g. biological diversity, conservation function, cultural or historical } \\
\text { meaning) } \\
\text { - Summary of the methodology carried out in the management plan. } \\
\text { - Description of the limitations and organizations of the management plan }\end{array}$ \\
\hline $\begin{array}{l}\text { General } \\
\text { description }\end{array}$ & $\begin{array}{l}\text { - Geographical and political localization, size, biophysical characteristics (e.g. } \\
\text { geological, geomorphological, climate, hydrological and vegetation characteristics), } \\
\text { land use, social, economical, historical, and cultural characteristics } \\
\text { - Legal status (e.g. local, regional, and national), management category, land tenure and } \\
\text { resources rights, governance issues, public services and access. This description can be } \\
\text { made with thematic maps. }\end{array}$ \\
\hline $\begin{array}{l}\text { Protected area } \\
\text { values }\end{array}$ & $\begin{array}{l}\text { - The protected areas normally created for biodiversity conservation. Nevertheless, the } \\
\text { other values can be important, as historical, cultural, archaeological, and social. } \\
\text { Contributions to local or national economy and ecosystem services should be also } \\
\text { considered. }\end{array}$ \\
\hline $\begin{array}{l}\text { Conservation } \\
\text { targets }\end{array}$ & $\begin{array}{l}\text { - Targets should mention the key items for protected area success. They should be } \\
\text { classified according to the degree of importance. } \\
\text { - The creation of targets allows us to create management objectives and be focused on } \\
\text { what it is important. }\end{array}$ \\
\hline $\begin{array}{l}\text { Management } \\
\text { objectives and } \\
\text { principles }\end{array}$ & $\begin{array}{l}\text { - The management should express the desire state of the protected area (e.g. biodiversity } \\
\text { and/or cultural and historical values). This should be always considered from a long- } \\
\text { term perspective. } \\
\text { - The management objectives should also describe the actions, expected results and } \\
\text { interventions needed for protected area conservation. The creation of objectives assist } \\
\text { in achievement of what we imagine of the protected area and what is required for their } \\
\text { realization } \\
\text { - The plan management is defined, normally, for } 5 \text { years. During this period the } \\
\text { management objectives should be specific, measurable, realistic, relevant, time bound, } \\
\text { and in priority order. } \\
\text { - Important questions to be considered in the protected area, they might be stakeholder } \\
\text { involvement, transparency, dispute resolution mechanisms, or internal governance } \\
\text { structures. }\end{array}$ \\
\hline $\begin{array}{l}\text { Opportunities } \\
\text { and constrains }\end{array}$ & $\begin{array}{l}\text { - The management of a protected area always meets opportunities and constrains. Here } \\
\text { potential pressures and their origin should be analyzed, evaluated, and quantified } \\
\text { - To understand the interaction between human activities and biodiversity the creation } \\
\text { of models is fundamental in this management stage. }\end{array}$ \\
\hline $\begin{array}{l}\text { Definition of } \\
\text { management } \\
\text { areas }\end{array}$ & $\begin{array}{l}\text { - The definition of management areas is achieved by probing into what can be allowed } \\
\text { or not (e.g. nature and cultural resources management, human use, visiting areas, } \\
\text { operations, and maintenance). } \\
\text { - Land use of the protected area is defined. }\end{array}$ \\
\hline $\begin{array}{l}\text { Management } \\
\text { strategies }\end{array}$ & $\begin{array}{l}\text { - The management strategies are interventions and important investments to achieve the } \\
\text { objectives. They should include area delimitation, surveillance, mitigation of human } \\
\text { pressure, interventions to restore the desired habitats, personal management and }\end{array}$ \\
\hline
\end{tabular}




\begin{tabular}{|c|c|}
\hline Elements & Contents \\
\hline & $\begin{array}{l}\text { education. } \\
\text { These interventions or tasks are carried out in activities or programs with realistic and } \\
\text { measurable objectives, deadlines and stakeholders. Important conditions to have an } \\
\text { effective management are: financing, staff and capacity building, areas demarcation, } \\
\text { probing, important species management, research, education, visitation, sustainable } \\
\text { use of resources, stakeholder involvement, conflict management and resolution and } \\
\text { governance. }\end{array}$ \\
\hline $\begin{array}{l}\text { Monitoring and } \\
\text { evaluation }\end{array}$ & $\begin{array}{l}\text { - The plan monitoring and evaluation aid, managers evaluate their effectiveness and } \\
\text { make the required corrections. It is important to observe the results of biodiversity } \\
\text { conservation, reduction of potential threats, and implementation of the management } \\
\text { activities. }\end{array}$ \\
\hline $\begin{array}{l}\text { Monitoring and } \\
\text { evaluation }\end{array}$ & $\begin{array}{l}\text { - The monitoring and evaluation should follow the management planning and compare } \\
\text { the obtained results with the baseline data. }\end{array}$ \\
\hline Financial plan & $\begin{array}{l}\text { - This plan should contain the protected area funds requirements, and the amount and } \\
\text { timing of this funding. To make an effective management it is fundamental to have } \\
\text { enough resources to meet the targets. } \\
\text { - The financial plan should consider the budget for the present and future activities and } \\
\text { should be frequently revised. }\end{array}$ \\
\hline Business plan & $\begin{array}{l}\text { - The business plan is important because it supports the protected area managers in their } \\
\text { work in identifying strengths, weaknesses, opportunities, and threats for improvement } \\
\text { of management. } \\
\text { - These plans rely on the financial policy that regulates the budget available for different } \\
\text { activities. } \\
\text { - Business strategy also identifies potential funding sources at short, medium and long } \\
\text { term, and assesses their risks. }\end{array}$ \\
\hline
\end{tabular}

The effective management of protected areas is widely recognized to be essential to its sustainability, and it is a fundamental tool at local, regional, and national levels (Hockings et al. 2006; Dudley et al. 2008). Good management of a protected area is to be based on a full and complete understanding of the protected area that includes a regular monitoring and potential changes in its work. To achieve it, a six step work is to be done (Fig. 2).

A key aspect of protected areas management is the social, economical and environmental context, which involves stakeholders, opportunities and threats, weaknesses, potentials, and political and management environment. The second step is planning, which defines the objectives, vision, strategies to protect and conserve the area of interest, to reduce the threats and weaknesses, and to enhance the opportunities and the potential. The plan envisages the management of the inputs (third step) available for staff and equipment needed to achieve the objectives and to implement the planned actions according to the process (fourth step), that will produce outputs (fifth step) as goods and services that result in outcomes (sixth step), normally considered in the management plans. These steps should reflect three topics presented in Figure 2: design/planning, adequacy/appropriateness, and delivery.

Management effectiveness is achieved throughout good practices (Hockings et al. 2009; Synge 2004). These practices should be also based on the knowledge of local people with their millenary land use. The contribution of local communities to success of the protected area plan and management allows managers to avoid a large number of conflicts (Alexander 2008; Lewis 1996). Among other practices, the use of fire is one of the most controversial, especially for the new generations, because of the idea that education and media give us information about the fire without any scientific validation (Pereira et al. 2010). Fire is an excellent tool for landscape management, when applied correctly. Thus, the incorporation of fire in the protected areas management plans assumes a great importance.

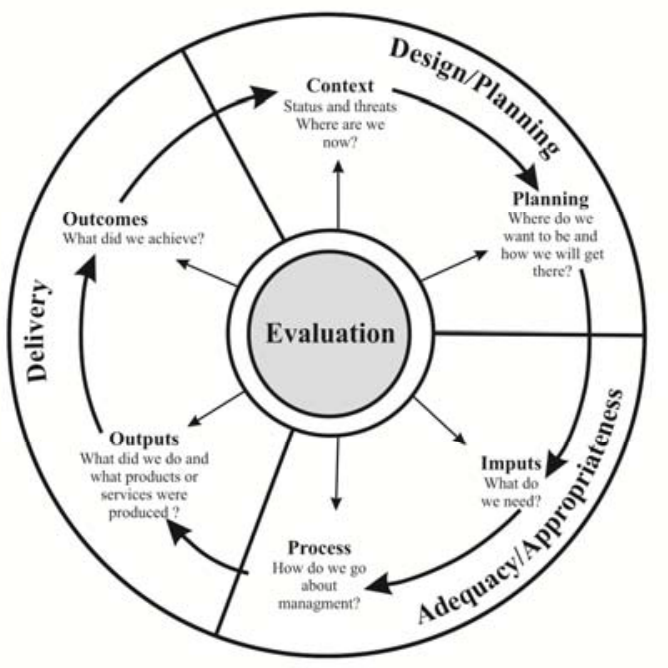

Fig. 2. $\quad$ Protected area management effectiveness cycle. Source: Hockings et al. (2006) 


\section{Fire in protected areas. A paradox}

Historically, after the areas were declared to be protected, management and human activities are restricted to sustain ecological function and biodiversity protection. Among these measures the use of fire is forbidden in order to maintain pristine conditions (Delong and Tanner 1996). Several places that we consider "untouched" were in fact shaped by flames and make part of protected areas ecology (Stahli et al. 2006; Josefsson et al. 2009, Shaffer 2010, White et al. 2011). The selective use of fire in protected areas created and maintained plant and animal refugee adapted to fire and sunny environments (Martinez 2003). It is widely known that fire is an important ecological agent and can improve and restore ecosystems, and it is important for biodiversity (Simberloff 1999). According to Weber and Stocks (1998), fire is an organizing factor of sustainability of Canadian natural parks ecosystems.

Due to a romantic view of the landscape, people, at least in the last 100 years, suppressed fire with serious implications for fire regimes. This intervention had negative impacts on the protected areas ecosystems (Tilman et al. 2000, MarsdenSmedley and Kirkpatrick, 2000, Bond and Kelley 2005). Fire regime is strongly influenced by cultural values, human practices, land use, fire suppression, and regional and national policies (White et al. 2011). The scheme of Figure 3 describes the interactions that determine the fire regime.

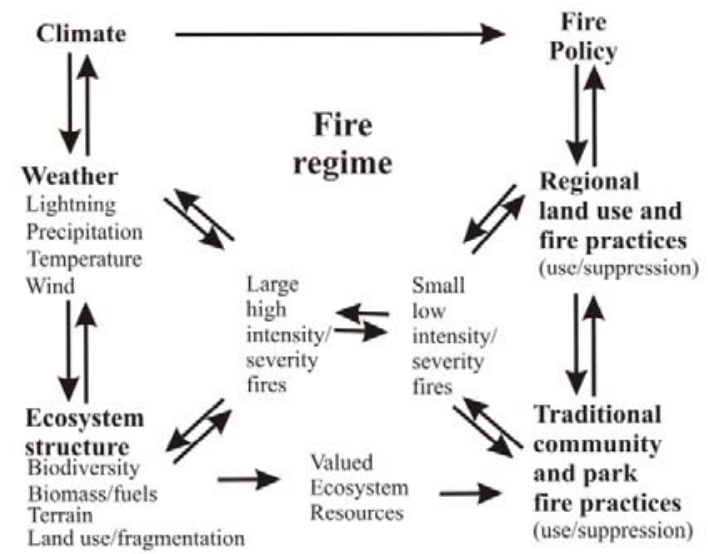

Fig. 3.

Conceptual model of the factors that affect fire regime in protected areas (Source: White et al. 2011)

Wildfire is a common visitor of protected areas, leading to environmental degradation, including landscape destruction, soil erosion, nutrients depletion, biodiversity loss, ecosystems change (vegetation and habitats, with implications for fauna sustainability), and air pollution. These changes can remain for from some months to several years. The ecosystem recuperation depends on the ecosystem vulnerability and resilience to this disturbance, vegetation pre/fire, topography, meteorological conditions, and human intervention (McKenzie 2010).
In addition, wildfires have important impacts on landuse as referred elsewhere (Mallinis et al. 2011). They have calamitous impacts on protected areas - lives lost, property lost, culture lost (e.g. cultural landscapes; historical monuments) and on rural communities that depend on forest resources and agriculture for their survival. These dramatic impacts can lead to conflicts and important economical losses (Molina-Martinez et al. 2011; Stetler et al. 2010).

Wildfires in Natura 2000 are increasing in number and in affected areas at a similar rhythm as in other non-protected areas (San-Miguel-Ayanz et al. 2008). In Portugal, this increase was considerable and their protected areas are frequently visited by wildfires (Pedrosa and Herrman 2007). For example, in the 2007 fire season (Fig. 4), more than 50\% of the burnt area occurred in Natura 2000. Natura 2000 areas in Iberian countries were the most affected by summer fires. In relation to the other Mediterranean countries, Natura 2000 areas were less affected in Cyprus (7.4\%). The total of burnt Natura 2000 areas was especially high in Greece, France and Italy, and less in France and Cyprus (Table 2).

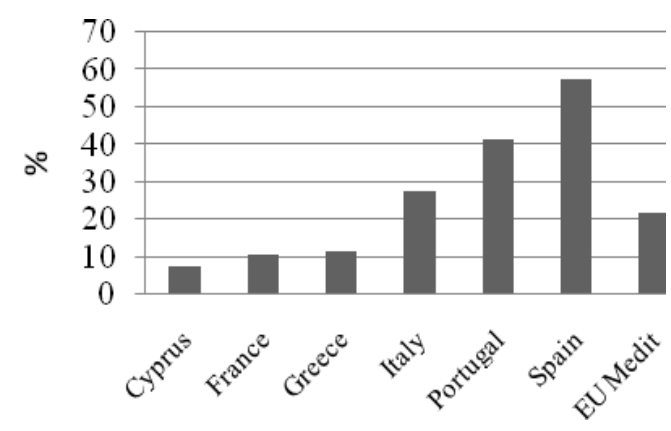

Fig.4. $\quad$ Percentage of Natura 2000 areas burnt in Mediterranean countries and Mediterranean Europe in 2007 (Source: San-Miguel-Ayanz et al., 2008)

Table 2. Total of the Natura 2000 burnt area in European Mediterranean countries in 2007 (Source: San-Miguel-Ayanz et al., 2008)

\begin{tabular}{||l|c|}
\hline \multicolumn{1}{|c|}{ Country } & Burned area (ha) \\
\hline Cyprus & 187 \\
\hline France & 245 \\
\hline Greece & 31.225 \\
\hline Italy & 36.929 \\
\hline Portugal & 3.774 \\
\hline Spain & 29.387 \\
\hline EU Medit. & 101.747 \\
\hline
\end{tabular}

Fire regime classifies, describes, and categorizes the pattern of fire occurrence for management and scientific purposes. This concept considers the fire extent (size of a determined fire), fire season (time of the year where fire occurs), fire frequency (how common fires occur in a given ecosystem), fire intensity (energy released per unit length of flame), 
and fire severity (ecological impacts of fire on the ecosystems). Naturally, the fire regime depends upon the type of vegetation, land use, climatic factors, and the interactions among all of them. Fire regime is also strongly influenced by humans. Anthropogenic causes of fire have influenced ecosystems for millennia in several parts of the world (Guyette et al. 2002; Colombaroli et al. 2008). During the last 10000 years fire regime changed due to the changes in the climate, vegetation, and human practices (Carcaillet et al. 2002).

However, since the beginning of the XX century, but especially in the last half, social conditions changed profoundly with important implications for the land-use and use of fire. In the last 50 years of the $\mathrm{XX}$ century, the rural exodus and sudden changes in the human millenary land use induced strong and perhaps never experimented changes in landscape dynamics. The rural abandonment (including the present protected areas) promotes the uncontrolled development of biomass, previously used by rural communities for energy, now it is accumulated in forests increasing its vulnerability to wildfires. In addition, the periodical use of fire by local population, who suddenly disappear inducing quick changes in millenary fire regime with unknown and perhaps pernicious impacts on the ecosystems, causes one more implication. Nowadays, the fire regime is mainly dominated by low regimen high severity wildfires (Pausas and Kelley 2009; White et al. 2011), instead of low severity fires beneficial for the ecosystems. Currently, urban population is returning back to rural areas (including the areas nearby protected ones), without the knowledge of the previous generations of how to manage the landscape, and without the perception of the risks that imply their life near the forest. The urban expansion increases the risk of forest to be affected by wildfire, and the exposition of human goods to the wildfire impact.

Climate change is another cause attributed to the increase in wildfire in protected areas and elsewhere (Klausmeyer and Shaw 2009). The prevalence of higher temperatures in long and drier summers does and will increase the wildfire risk (Midgley et al. 2002). Considering this, the management of protected areas assumes a great relevance, especially when dealing with uncertainty imposed by climate change impacts and measures to prevent it.

Fire can be a good tool or a bad visitor, depending on how we deal with it. From this paradox many problems concerning fire policy have emerged. Referring to Figure 3, landscape management depends strongly on the political option. If we choose the extreme protection of protected areas, it is very likely that a probability of being visited by wildfires will be higher. On the contrary, the option of the respect for local traditions can strongly reduce this probability. This simple choice can have tremendous implications for the environment and especially for economical and social conditions.

\section{Effects of fire in protected areas. More than an "Environmental Problem"}

Fire effect is not an environmental problem. Many of the ecosystems that we protect were actually influenced or created by fire. For example, grassland ecosystems around the world were strongly influenced by fire. Without the existence of fire, such ecosystems would be substituted by forests (Bond et al. 2005; van Wilgen 2009). Fire favors the spread of grasses and the creation of numerous ecosystems that nowadays are considered to be key habitats for many species of herbs, grazing animals, butterflies, reptiles, and birds. Grasslands are the largest habitat in the world with an estimated area of 52.5 million $\mathrm{km}^{2}$ in the world or $40.5 \%$ of landmass (FAO 2005). In the EU the grasslands are habitats with great biodiversity. Nowadays, in the EU countries the grassland area decreased by $12.8 \%$ in the period of $1990-2003$. Among other causes (e.g. afforestation, intensive agriculture, and land-use change), the abandonment of traditional activities, including fire, are responsible for this decrease (European Commission 2008). Other ecosystems protected under the Natura 2000 framework, especially in a Mediterranean region, as Schlerophylus scrub (Matorral) and Forests (Quercus spp forests) are resistant to fire impacts and can easily recover after fire disturbances (Gratani and Amadori 1991; Lloret and Zedler 2009; Moya et al. 2011; Meira-Neto et al. 2011). Boreal ecosystems were also strongly shaped by fire (Weber and Stocks 1998). Herewith, the effects of fire in the protected areas might be especially social and economical, since ecosystems and plants have developed strategies of adaptation to the fire impact. The effects of fire in socio-economical spheres are substantially enhanced by the lack of landscape management and the lack of plans that consider fire management.

\section{Management of protected areas with fire}

In protected areas fire can be used as a tool for landscape management. Fire can enhance the recruitment of desired species to maintain habitat diversity and structure. The sustainable use of fire can be an opportunity to maintain traditional land-uses, restore ecosystems and fuel management (Taggart et al. 2009).

Fires and their impact have to be managed and should include social, economical, cultural, and ecological variables, with the aim of minimizing the damage and maximizing the benefits (Rego et al. 2010). The strategies to combat wildfires are divided into suppression strategies, and prevention strategies (Fig. 5).

Fire suppression strategies are based on the idea of the application of fire to combat wildfires. It is an intentional application of fire to speed up or to strengthen the fire suppression and it was used by local population. In situations of uncontrolled wildfires this technique is very useful to extinguish 
them (Montiel et al. 2010), but not to protect the land from wildfires.

Strategies based on fire suppression exclude the use of fire in landscape management. Fire suppression had important implications for natural fire regimens, increasing burnt size and fire severity with impacts on the protected area ecosystems (Bridge et al. 2005; Martell and Sun 2005; Miller et al. 2009; Higgs and Roush 2011), including vegetation type and structure (Sands and Abrams 2011), biodiversity reduction, and faunal composition and behavior (Bond and Keeley 2005; Pasch and Koprowski 2011). Decades of fire suppression have changed natural fire regimens, habitats, vegetation, and fauna in protected areas (Miller and Davies 2009). Forest fire suppression strategies decrease biodiversity (Barber et al. 2004), and the policies based on fire suppression increase the importance of large fires (Castellnou et al. 2010). Models about the effects of fire policies in the warmer climate showed that the increase in fire suppression and fire exclusion in protected areas could lead to the loss and decline of species (De Groot et al. 2009).

It is clear that suppression of fire is not an adequate strategy for the fire management from the ecological point of view - it is creating flammable landscapes (Bowman et al. 2011) with unknown and tremendous impacts on protected areas. To some extent in determined ecosystems fire is an important ecological element of the protected areas management, on certain occasions it is important to let natural fires burn and to manage the other areas with prescribed fire (Barber et al. 2004).

Prevention strategies are much more advantageous in the fire management, including fire with prescription and traditional burning (Fig. 5). Fire with prescription considers the application of fire by firemen to landscape management proposals. These strategies consider that 1 ) the prescribed fire is the application of fire under certain environmental conditions, it is normally confined to a plot and has management objectives, and 2) wildfire with prescription is also applied to a plot, normally for research, fire fighters' training, and landscape management (Rego et al., 2010). The management of protected areas with prescribed fire is a great advantage in maintaining the natural fire regimens and protecting them from wildfire building firebreaks (Boer et al. 2009). Suffling et al. (2009) observed that the application of prescribed fire as a firebreak strategy had been able to reduce by $77-90 \%$ the effect of wildfires on Quetico regional park in Canada.

The effects of prescribed season fire on the ecosystems are a matter of discussion. Normally, spring fires consume less fuel than the others observed in other seasons (Knapp et al. 2009). Some studies advocate that spring fires are more advantageous and do not have significant impacts on the ecosystems (Slocum et al. 2003; Trappe et al. 2009; Harrod et al. 2009; Zhou et al. 2009). Other studies showed no important differences between seasons (Monroe and Converse 2006; Willcox and Giulliano 2010). The impacts of prescribed fire on the ecosystems depend essentially on the ecosystem affected and the fire intensity/severity observed (Knapp et al. 2009).

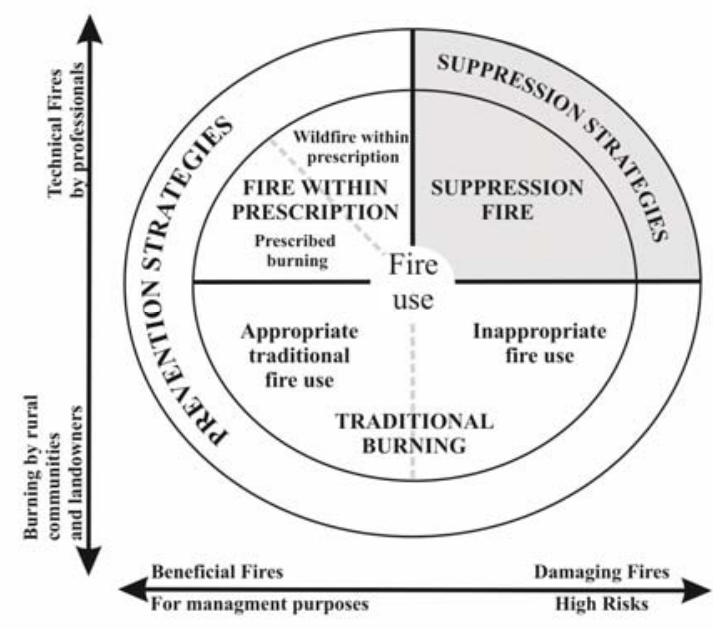

Fig. 5.

Integrated fire management (Source: Rego et al. 2010)

The other possibility of protected areas management is allowing cultural traditions to be continued as traditional burnings. Fire is used by indigenous people to manage habitats, maintain their resources, and prevent the spread of wildfires in the protected area. To some extent, it is a practice of their daily lives. The use of fire alleviates their travel on the land, their guard and communication, clearing of an infested area, and it improves visibility for hunting (Beltran 2000). Several examples come from some parts of the world. In Canada, the cultural burns maintain the long-term fire regimen and some important lessons have been learned, since fire is an ecosystem process with positive and negative impacts, and the role and importance of fire in the past, present, and future ecological and cultural status of the protected areas are an important link between managers and stakeholders (White et al. 2011). In Reserva Especial de Maputo, Mozambique, indigenous people use fire according to their needs and have an important knowledge about the fire effects on the landscape ecology. In Savanna ecosystem, the fire helps open the forest, maintain the landscape opened, and reduce or remove the invasive species. In the protected area, natives and managers use fire to increase biodiversity, which means greater availability of food, medicines, and development of native species (Shaffer 2010). In Tasmania wilderness world heritage area, the use of fire by natives prevents the unplanned ignitions, favors the existence of rare species, and reverses degradation o the ecosystem (Mardsen-Smedley and Kirkpatrick 2000).

The use of fire in protected area management has been progressively introduced and the role of fire in protected areas has a positive relation with management, forest health, and biodiversity (Kilgore 2005). However, many efforts and research have to be done to acquire clear understanding of the fire effects on sensitive and protected habitats. 


\section{Conclusions}

Fire is a great disturbance in the ecosystems, but it is also an important ecological element, fundamental for the landscape sustainability. On the one hand, many of the ecosystems shaped and created by fire (e.g. grasslands) are today protected. On the other hand, wildfire is increasing in protected areas, one of its causes being our excessive protection, especially with the policies focused mainly on fire suppression. Thus, the effect of our protection is degradation of protected habitats caused by the fire exclusion in communities shaped by fire. In addition, this fire suppression leads to the fuel accumulation that can destroy the habitat and it also increases vulnerability of protected areas to severe wildfire occurrence. Policies focused on wildfire prevention must be considered with great care, including the use of prescribed fire and allow traditional burning to maintain fire regimen in the ecosystems. The incorporation of fire in protected areas management will strongly enhance management effectiveness, creating a link between traditional land uses and landscape sustainability, and, as consequence, will reduce potential conflicts with local communities.

\section{Acknowledgements}

The authors are thankful for the support of the project "Litfire", Fire effects in Lithuanian soils and ecosystems (MIP-048/2011) funded by the Lithuanian Research Council, Spanish Ministry of Science and Innovation for funding through the HYDFIRE project CGL2010-21670-C02-01, FUEGORED (Spanish Network of Forest Fire Effects on Soils http://grupo.us.es/fuegored/) and to Commissionat per a Universitats i Recerca del DIUE de la Generalitat de Catalunya.

\section{References}

Alexander, M. Management planning for nature conservation. Springer Science B.V. 2008, 314 p. http://dx.doi.org/10.1007/978-1-4020-6581-1

Barber, V., Miller, K.R., Boness, M., Securing protected areas in the face of the global change: Issues and strategies, IUCN, Gland, Switzerland and Cambridge, 2004, p. 234.

Beltran, J. Indigenous and traditional peoples and protected areas. Principles guidelines and case studies IUCN, Gland, Switzwerland, and Cambridge, UK, 2000, p. 133.

Boer, M.M., Sadler, R.J., Wittkuhn, R.S., McCaw, L., Grierson, P.F., Long-term impacts of prescribed burning on regional extend and incidence of wildfires - Evidence from 50 years of active fire management in SW Australian forests, Forest Ecology and Management, 259(1), 2009, 132-142. http://dx.doi.org/10.1016/j.foreco.2009.10.005

Bond, W.F., Woodward, F.I., Midgley, G.F., The global distribution of ecosystems in a world without fire, New Phytologist, 165(2), 2005, 525-538. http://dx.doi.org/10.1111/j.1469-8137.2004.01252.x
Bond, W.J., Keeley, J.E. Fire as a global herbivore: the ecology and evolution of flammable ecosystems, Trends in Ecology and Evolution, 20(7), 2005, p. 387-394. http://dx.doi.org/10.1016/j.tree.2005.04.025

Bouwma. I.M., R. van Apeldoorn, D.A. Kamphorst. Current practices in solving multiple use issues of Natura 2000 sites: Conflict management strategies and participatory approaches. Alterra, Wageningen, the Netherlands, 2010, p 75.

Bowman, D.M.J.S., Balch, J., Artaxo, P., Bond, W.J., Cochrane, M.A., D‘Antonio, C.M., DeFries, R., Johnston, F.H., Keeley, J.E., Krawchuk, M.A., Kull, C.A., Mack, M., Moritz, M., Pyne, S., Roos, C.I., Scott, A.C., Sodhi, N.S., Swetnam, T.W., The human dimension of fires regimens on earth, Journal of Biogeography, 38(12),2011, 2223-2236. http://dx.doi.org/10.1111/j.1365-2699.2011.02595.x

Bridge, S.R.J., Miyanishi, K., Johnson, E.A., A critical evaluation of fire suppression effects in the boreal forest of Ontario, Forest Science, 51(1), 2005, 41-50.

Carcaillet, C., Almquist, H., Asnong, H., Bradshaw, R.H.W., Carrion, J.S., Gaillard, M.J., Gajewski, K., Haas, J.N., Haberle, S.G., Hadorn, P., Muller, S.D., Richard, P.J.H., Richoz, I., Rosch, M., Sanchez-Goni, M.F., von Stedink, H., Stevenson, A.C., Talon, B., Tardy, C., Tinner, W., Tryterud, E., Wick, L., Wills, K.J. Holocene biomass burning and global dynamcs of carbon cycle, Chemosphere, 49 (8), 2002, 845-863. http://dx.doi.org/10.1016/S00456535(02)00385-5

Castellnou, M., Kraus, D., Miralles, M., Delogu, G., Suppression fire use in learning organizations. In: Silva, J.S., Rego, F., Fernandes, P., Rigolot, E. (eds) Towards Integration Fire Management - Outcomes from the European Project Fire Paradox, European Forest Institute Research Report 23, Joensuu, Finland, 2010, p. 189-201.

Cole, D.N., Wilderness, protected areas and climate change. U.S. Department of agriculture, Forest service, Climate change resource centre, 2008. Available in (http://www.fs.fed.us/ccrc/topics/wilderness.shtml)

(Consulted in 15 of November, 2011).

Colombaroli, D., Vanniere, B., Emmanuel, C., Magny, M., Tinner, W. Fire-vegetation interactions during the Mesolithic-Neolithic transition at lago dell'Accesa, Tuscany, Italy, The Holocene, 18(5), 2002, 679-692. http://dx.doi.org/10.1177/0959683608091779

Curran, L.M., Trigg, S.N., McDonald, A.K., Astiani, D., Hardiono, Y.M., Siregar, P., Caniago, I., Kasischke, E. Lowland forest loss in protected areas of Indonesian Borneo, Science, 303, 2004, 1000-1003. http://dx.doi.org/10.1126/science.1091714

De Groot, W.J., Flannign, M.D., Cantin, A. Adapting fire management to future fire regimens: impact on boreal forest composition and carbon balance in Canadian National Parks, EGU General Assembly 2009,13659.

Delong, S.C., Tanner, D., Managing the pattern of forest harvest: lesson form wildfire, Biodiversity and Conservation, 5, 1996, 1191-1205. http://dx.doi.org/10.1007/BF00051571

Dudley, N., Guidelines to applying Protected Area Management Categories, Gland, Switzerland, 2008, p. 86. http://dx.doi.org/10.2305/IUCN.CH.2008.PAPS.2.en

European Commission., Life and Europe's grassland. Restoring a forgotten hábitat, Luxembourg: Office for Official Publications of the European Communities, 2008, p. 56.

FAO Grasslands of the world, Plant Production and Protection Series No. 34, 2005, p. 514.

Gratani, L., Amadori, M., Post-fire resporuting shrubby species in mediterranan maquis, Vegetacio, 
96(2),1991,

http://dx.doi.org/10.1007/BF00044975

$137-143$

Guyette, R.P., Muzika, R.M., Dey, D.C. Dynamics of anthropogenic fire regime, Ecosystems, 5, 2002, 472-486.

Harrod, R.J., Petersen, D.W., Povak, N.A., Dodson, E.K., Thinning and prescribed fire effects on overstorey tree and snag structure in dry conniferous forest in the interior of Pacific Northwest, Forest Ecology and Management, 258 (5), $712-721$. http://dx.doi.org/10.1016/j.foreco.2009.05.011

Higgs, E.S., Roush, W.M., Restoring remote ecosystems, 19(5), 2011, 553-558.

Hockings, M., Cook, C.N., Cater, R.W., James, R. Accountability, reporting, or management improvement? Development of a state of the parks assessment system in New South Wales, Australia. Environmental Management, 2009, 43, 1013 - 1025. http://dx.doi.org/10.1007/s00267009-9277-9

Hockings, M., Stolton, S., Leverington, F., Dudley, N., Courrau, J. Evaluating effectiveness: A framework for assessing management effectiveness of protected areas, IUCN, Gland, Switzerland and Cambridge, $2^{\text {nd }}$ Edition, 2006, p. http://dx.doi.org/10.2305/IUCN.CH.2006.PAG.14.en

Josefsson, T., Hornberg, G., Ostlund, L., Long-term human impact and vegetation changes in boreal forest reserve: Implications for the use of protected areas as ecological references, Ecosystems, 12(6), 2009, 1017-1036. http://dx.doi.org/10.1007/s10021-009-9276-y

Kilgore, B.M., Fire management in parks and protected areas: Introduction and summary, The George Wright Forum, 22(4), 2005, 8-11.

Klausmeyer, K.R., Shaw, M.R. Climate change, habitat loss, protected areas and climate adaptation potential of species in Mediterranean ecosystems worldwide, $\begin{array}{lll}\text { Plosone, } & 4(7), & 2009,\end{array}$ http://dx.doi.org/10.1371/journal.pone.0006392

Knapp, E.E., Estes, B.L., Ecological effects of prescribed fire season: A literature review and synthesis for managers, General technical report, United States department of agricultura, 2009, p. 80.

Leverington, F., Costa, K.L., Courrau, J., Pavese, H., Nolte, C., Marr, M., Coad, L., Burgess, N., Bomhard, B., Hockings, M. Management effectiveness evaluation in protected areas - a global study. Brisbane, Australia, $2^{\text {nd }}$ Edition, 2010, p. 87.

Lewis, C., Managing conflicts in protected areas. IUCN, Gland, Switzwerland, and Cambridge, UK, 1996, p. 100.

Lloret, F., Zedler, P.H., The effect of fire on vegetation. In: Cerda, A., Robichaud, P. (eds) Fire effects on soils and restoration strategies, Science Publishers, Enfield, 2009, p. 257-295. http://dx.doi.org/10.1201/9781439843338-c9

Mallinis, G., Emmanoloudis, D., Guannakopoulos, V., maris, F., Mapping and interpreting historical land cover and land uses in natura 2000 site using earth observational data: The case of Nestos delta, Greecde, Applied Geography, 31(1), 2011, 312-320. http://dx.doi.org/10.1016/j.apgeog.2010.07.002

Marsden-Smedley, J.B., Kirkpatrick, J.B., Fire management in Tansmania wilderness world heritage area: Ecosystem restoration using indegenous-style fire regimens?, Ecological Management and Restoration, 1(3), 2000, 198-203. http://dx.doi.org/10.1046/j.14428903.2000.00052.x

Martell, D.L., Forest fire management, current practices and new challenges for operational researchers. In: Weintraub, A., Romero, C., Bjorndal, T., Epstein, R. (eds)
Handbook of operations research in natural resources, International Series in Operations Research \& Management $\begin{array}{llll}\text { Science, } & \text { 2007, 419-509. }\end{array}$ http://dx.doi.org/10.1139/X07-210

Martell, D.L., Sun, H., The impact of fire suppression, vegetation, and weather on the area burned by lighting causes forest fires, Canadian Journal of Forest Research, 38, 2005, 1547-1563.

Martinez, D., Protected areas, Indigenous peoples, and the western idea of nature, Ecological Restoration, 21(4), 2003, 247-250. http://dx.doi.org/10.3368/er.21.4.247

Mataix-Solera, J., Cerdà, A. Incendios forestales en España. Ecosistemas terrestres y suelos. In: Cerdà, A., Mataix-Solera, J. (eds) Efectos de los incendios forestales sobre los suelos en España, Catedra de Divulgación de la Ciencia. Universitat de València. València, 2009, p. 27-53.

McKenzie, D., The effects of climate change and wildland fires on air quality in national parks and wilderness areas, Fire Management Today, 70(1), 2010, 26-28.

Meira-Neto, J.A.A., Clemente, A., Oliveira, G., Nunes, A., Correia, O., Post-fire and post-quarry rehabilitation successions in Mediterranean like ecosystems: implications for ecological restoration, Ecological Engennering, 37(8), 2011, 1132-1139. http://dx.doi.org/10.1016/j.ecoleng.2011.02.008

Midgley, G.F., Hannah, L., Millar, D., Rutherford, M.C., Powrie, L.W. Assessing the vulnerability of species richness to anthropogenic climate change in biodiversity hotspot, Global Ecology and Biogeography, 11(6), 2002, 445-451. 822X.2002.00307.X

Miller, C., Davies, B., Quantifying the consequences of fire suppression in two California national parks, The George Wright Forum, 26(1), 2009, 76-88.

Miller, J.D., Safford, H.D., Crimmimgs, M., Thode, A.E., Quantitative evidence for increasing forest fire severity in the Sierra Nevada and Southern Cascade Mountains, California and Nevada, USA, Ecosystems, 12(1), 2009, 16-32. http://dx.doi.org/10.1007/s10021-0089201-9

Molina-Martinez, J.M., Machuca, M.E., Diaz, R.Z., Rodriguez y Silva, F., Gonzalez-Caban, A., Economic losses to Iberian swine production due forest fires, Forest Policy and Economics, 13, 2011, 614-621. http://dx.doi.org/10.1016/j.forpol.2011.07.011

Monroe, M.E., Converse, S.J., The effects of early season and late season prescribed fire on small mammals in Sierra Nevada mixed forest, Forest Ecology and management, 236(2-3), 229-240. http://dx.doi.org/10.1016/j.foreco.2006.09.008

Montiel, C., Costa, P., Galan, M., Overview of suppression fire policies and practices in Europe. In: Silva, J.S., Rego, F., Fernandes, P., Rigolot, E. (eds) Towards Integration Fire Management - Outcomes from the European Project Fire Paradox, European Forest Institute Research Report 23, Joensuu, Finland, 2010, p. 177 - 187.

Moya, D., De las Heras, J., Ferrandis, P., Herranz, J.M., Martinez-Sanchez, J.J., Fire resistance and forest regeneration in Mediterranean fire phrone-areas, Technology and Knowledge Transfer e-bulletin, 2(3), 2011, $1-5$.

Nolte, C., Leverington, F., Kettner, A., Marr, M., Nielsen, G., Bomhard, B., Stolton, S., Stoll-Kleemann, S., Hockings, M. Protected area management effectiveness assessment in Europe. A review of application, methods and results, BfN-Skripten, Bonn, 2010, p. 69.

Pasch, B., Koprowski, J.L., Impacts of fire suppression on space use by Mexican fox squirrels, Journal 
of Mammalogy, 92(1), 2011, 227-234. http://dx.doi.org/10.1644/10-MAMM-A-133.1

Pausas, J.G., Keeley, J.E. A Burnning Story: The role of fire in the history of life, Bioscience, 59(7), 2009, 593601. http://dx.doi.org/10.1525/bio.2009.59.7.10

Pedrosa, F.T., Herrmann, M.L.P. Forest fires in Protected areas and in the state of Santa Catarina (Brazil): Comaprative análisis of policies of prevention and ecovery of burned areas. Forest Fires in Protected Areas, Sevilla, 2007. available in (http://www.fire.uni-freiburg.de/sevilla2007/contributions/doc/cd/SESIONES_TEMATICAS/ST8/ Pedrosa_Herrman_PORTUGAL.pdf) (Consulted in: 5-112011).

Pereira, P., Braga, R. Sustainable use of protected areas: The example of the Albufeira Coastal Lagoon (Portugal), Darnaus vysymosi strategija ir praktika, 1(3), 2009, 111-125.

Pereira, P., Úbeda, X., Mataix-Solera, J., Cerdà, A Forest management using prescribed fires: Opportunities and barriers, Darnaus vysymosi strategija ir praktika, 1(4), 2010, 81-95.

Ramos-Neto, M.B., Pivello, V.R. Lightning Fires in a Brazilian Savanna National Park: Rethinking Management Strategies, Earth and Environmental Science, 26(6), 2000, 675-684.

Rego, F., Rigolot, E., Fernandes, P., Montiel, C., Sande Silva, J. Towards Integrated Fire Management, European Forest Institute, Joensuu, Finland, 2010, 16.

Sands, B.A., Abrams, M.D., A 183-year history of fire and recent fire suppression impacts in select pine and oak forest stands of the Menominee Indian reservation, Winscosin, The American Midland Naturalist, 166(2), 2011, 325-338 http://dx.doi.org/10.1674/0003-0031-166.2.325

San-Miguel-Ayanz J., Camia A., Liberta G., Boca, R. Analysis od forest fire damages in Natura 2000 sites during the 2007 fire season, Joint Research Center, Institute for Environment and Sustainability. Luxemburg, 2008. p. 36.

Shaffer, L.N. Indigenous fire use to manage savanna landscapes in Southern Mozambique, Fire Ecology, 6(2), 2010, 43-59. http://dx.doi.org/10.4996/fireecology.0602043

Simberloff, $\mathrm{D}$. The role of science in the preservation of forest biodiversity, Forest Ecology and Management, 115(2), 1999, 101-111. http://dx.doi.org/10.1016/S03781127(98)00391-0

Slocum, M.G., Platt, W.J., Cooley, H.C., Effects of differences in prescribed fire regimens on patchiness and intensity of fires in subtropical savannas of Everglades national park, Restoration Ecology, 11(1), 2003, 91-102. http://dx.doi.org/10.1046/j.1526-100X.2003.00115.x

Stachura-Skierczynska, K., Walsh, M. Against the grain: Improving the management of NATURA 2000 sites and other forests in the EU. BirdLife European Forest Task Force 2010, p. 38.

Stahli, M., Finsinger, W., Tinner, W., Allgower, B. Wildfire history and fire ecology of the Swiss National Park (Central Alps): New evidence from charcoal, pollen and plant macrofossils, The Holocene, 16(6), 2006, 805-817. http://dx.doi.org/10.1191/0959683606hol967rp
Stetler, K.M., Venn, T.J., Calkin, D.E. The effects of eildfire and environmental amenities on property values in northwest Montana. Ecological Economics. Vol. 69. No. 11. pp. 2233-2243. http://dx.doi.org/10.1016/j.ecolecon.2010.06.009

Suffling, R., Grant, A., Feick, R., Modeling prescribed burns to serve regional firebreaks to allow wildfire activity in protected areas, Forest Ecology and Management, 256(11), 2009, 1815-1824. http://dx.doi.org/10.1016/j.foreco.2008.06.043

Synge, H. European models of good practice in protected areas, IUCN, Gland, Switzerland, and Cambridge, UK, 2004, p. 32.

Taggart, J.B., Ellis, J.M., Sprouce, J.D., Prescribed fires in state park properties of north Carolina and nearby coastal states, Natural Areas Journal, 29(1), 2009, 64-70. http://dx.doi.org/10.3375/043.029.0108

Thackway, R., Olsson, K. Public/ private partnerships and protected areas: selected Australian case studies, Landscape and Urban Planning, 44(2-3) 1999, 87-97. http://dx.doi.org/10.1016/S0169-2046(99)00003-1

Tilman, D., Reich, P., Philips, H., Menton, M., Patel, E., Vos, E., Peterson, D., Knops, J. Fire suppression and ecosystem carbon storage, Ecology, 81, 2000, 2680-2685. http://dx.doi.org/10.1890/00129658(2000)081[2680:FSAECS]2.0.CO;2

Trappe, M.J., Cromack Jr., K., Trappr, J., Perrakis, D.D.B., Cazares-Gonzalez, E., Castellano, M.A., Miller, S., Interations among prescribed fire, soil attributes and Mycorrhizal community structure at creater lake national park, Oregon, USA, Fire Ecology, 5(2), 2009, 30-50. http://dx.doi.org/10.4996/fireecology.0502030

Van Wilgen, B.W., The evolution of fire management practices in savanna protected areas in South Africa, South African Journal of Science, 105(9-10), 2009, 343-349.

Weber, M.G., Stocks, B., Forest fires and sustainability in the boreal forests of Canada, Ambio, 27(7), 1998, 545-550.

White, C.A., Perrakis, D.D.B., Kafka, V.G., Ennis, T. Burning at the edge: Integrating biophysical and Ecocultural fire process in Canada's Parks and protected areas, 7(1), 2011, 74-106.

Willcox, E.V., Giulliano, W.M., Seasonal effects of prescribed burning and roller chopping on saw palmetto in flatwoods, Forest Ecology and Management, 259(3), 2010, 1580-1585. http://dx.doi.org/10.1016/j.foreco.2010.01.034

Wittemeyer, G., Elsen, P., Bean, W.T., Coleman, A., Burton, O., Brashares, J.S., Accelerated population growth at Protected area edges, Science, 321(5885), 123-126. http://dx.doi.org/10.1126/science.1158900

Zhou, L., Huang, J., Lu, F., Han, X., Effects of prescribed fire burning and seasonal interanual vlimate variation on nitrogen mineralization in a typical steepe in Inner Mongolia, Soil Biology \& Biogeochemistry, 41(4), 2009,

http://dx.doi.org/10.1016/j.soilbio.2009.01.019
796-803. 
Dr. Paulo Pereira, assoc. prof. at the Environmental Policy Department, Mykolas Romeris University.

Main research areas: Fires effects on the ecosystems, ecosystems modeling, protected areas management, soil erosion.

Address:

Ateities str. 20

Tel.:

LT-08303 Vilnius, Lithuania

Fax:

$+370-5-2714551$

E-mail:

+370-5-2740624

pereiraub@gmail.com

Assoc. prof. dr. Pranas Mierauskas, head of the Environmental Policy Department, Mykolas Romeris University.

Main research areas: nature conservation policy, protected areas management, ecological evaluation, stakeholder participation in environmental governance.

Address:

Ateities str. 20

Tel.:

LT-08303 Vilnius, Lithuania

Fax:

$+370-5-2714551$

E-mail:

mierauskas@mruni.eu
Dr. Xavier Ubeda, assoc. prof. at the Department of Physical Geograpgy and Geographic Regional Analysis, University of Barcelona

Main research areas: Fires effects on the ecosystems, soil erosion, catchment hydrology.

Address: $\quad$ Montalegre 20,

08001 Barcelona, Spain

Dr. Jorge Mataix-Solera, assoc. prof. at the Department of Agrochemistry and Environment. Miguel Hernández University.

Main research areas: Fires effects on the ecosystems, soil erosion.

Address: $\quad$ Avda. de la Universidad s/n.,

Alicante, Spain

E-mail:_ jorge.mataix@umh.es

Dr. Artemi Cerda, prof. at the Department of Geography, University of Valencia, Valencia, Spain Main research areas: Fires effects on the ecosystems, soil erosion

Address $\quad$ Av. $\quad$ Blasco Ibáñez, 13.

46010 València, Spain

E-mail: $\quad$ artemio.cerda@uv.es 